\title{
A “CRIAÇÃO” DA FACULDADE DE DIREITO DA UFRJ (FND) E O ENSINO JURÍDICO NO BRASIL EM 1891: ESTUDO ANALÍTICO DE ASPECTOS DA REFORMA BENJAMIN CONSTANT REFERENTES ÀS FACULDADES LIVRES
}

\section{THE “CREATION” OF UFRJ'S LAW SCHOOL (FND) AND LEGAL EDUCATION IN BRASIL IN 1891: ANALYTICAL STUDY OF ASPECTOS OF BENJAMIN CONSTANT'S REFORM REGARDING THE FREE FACULTIES}

\section{ALEXANDre FERREIRA ASSUMPÇÃo ALVES ${ }^{1}$}

RESUMO: Elabora-se o presente artigo no ano em que a Faculdade de Direito da UFRJ, conhecida por seus ex-alunos como "FND", comemora 130 (cento e trinta) anos do início de suas atividades, na condição de docente ex-aluno integrante da "turma centenário" (denominação recebida em razão da conclusão do curso de bacharelado no ano do centenário). Este trabalho tem por objetivo apresentar ao leitor (ou revistar, dependendo do seu conhecimento prévio sobre a trajetória da FND) uma visão recortada do ensino jurídico em 1891, consubstanciado em aspectos do Decreto $\mathrm{n}^{\mathrm{o}}$ 1.232-H, de 2 de janeiro (Reforma Benjamin Constant) referentes às Faculdades Livres.

Palavras-Chave: Faculdade Nacional de Direito; Reforma Benjamin Constant; Ensino Jurídico; Faculdades Livres.

ABSTRACT: The present article is elaborated in the same year that the UFRJ's Faculty of Law, known by it's former students as "FND", celebrates its 130 (one hundred and thirty) years since the beginning of its activities, as a teacher and former student from the "centenial class" (name received due to the conclusion of the bachelor's degree in the year of the centenary). This work aims to present the reader (or to review, depending on their previous knowledge of the FND's trajectory) a cropped view of legal education in 1891, embodied in aspects of the

1 Professor de Direito da Universidade Federal do Rio de Janeiro (FND - UFRJ), professor do programa de pós-graduação stricto sensu da UFRJ na linha de pesquisa Empresa e Atividades Econômicas. É membro do Conselho Editorial da Revista Semestral de Direito Empresarial (RSDE). Pesquisador líder do grupo de pesquisa Empresa e Atividades Econômicas, do DGP do CNPq. Expositor convidado na Escola da Magistratura do Estado do Rio de Janeiro (EMERJ) desde 1994. Possui graduação em Direito pela UFRJ, mestrado em Direito pela UERJ, e doutorado em Direito pela UNIRIO. 
Decree $\mathrm{n}^{\mathrm{o}}$ 1.232-H, of January 2nd (Benjamin Constant's Reform) referring to the Free Faculties.

KEYWORDS: National Faculty of Law; Benjamin Constant's Reform; Legal Education; Free Faculties.

\section{INTRODUÇÃO}

Elabora-se o presente artigo no ano em que a Faculdade de Direito da UFRJ, conhecida por seus alunos e ex-alunos como "FND", comemora 130 (cento e trinta) anos do início de suas atividades ${ }^{2}$, na condição de docente ex-aluno integrante da "turma centenário" (denominação recebida em razão da conclusão do curso de bacharelado no ano do centenário).

O trabalho tem por objetivo apresentar ao leitor (ou revistar, dependendo do seu conhecimento prévio sobre a trajetória da FND) uma visão recortada do ensino jurídico em 1891, consubstanciado em aspectos do Decreto no $1.232-\mathrm{H}$, de 2 de janeiro (Reforma Benjamin Constant) referentes às Faculdades Livres. O Decreto $\mathrm{n}^{\mathrm{0}}$ 1.232-H é referenciado no Ato de autorização do curso de Direito da UFRJ, Decreto $n^{0}$ 639, de 31 de outubro do mesmo ano ${ }^{3}$. O primeiro diploma aprovou o Regulamento das Instituições de Ensino Jurídico dependentes do Ministério da Instrução Pública, antecessor do Ministério da Educação.

A Faculdade Nacional de Direito, ou simplesmente Faculdade de Direito, é uma unidade acadêmica da Universidade Federal do Rio de Janeiro (exUniversidade do Brasil) desde 1920. A FND é resultado da junção de duas Faculdades Livres de Direito (particulares) que funcionavam na cidade do Rio de Janeiro: a Faculdade Livre de Ciências Jurídicas e Sociais do Rio de Janeiro, fundada em 18 de abril de 1882, mas autorizada a funcionar, nesse condição, apenas em 1891, ano em que lhe foi concedido o título de Faculdade Livre, e a Faculdade Livre de Direito do Rio de Janeiro, constituída e instalada no mesmo

\footnotetext{
2 De fato, a Faculdade Livre de Ciências Jurídicas e Sociais do Rio de Janeiro, uma das antecessoras da Faculdade Nacional de Direito, foi criada em 18 de abril de 1882 por iniciativa do Dr. Fernando Mendes de Almeida, seu primeiro diretor, formado pela Faculdade de Direito de São Paulo em 1879. Todavia, somente em 1891 foi autorizado o funcionamento do curso, juntamente com o da Faculdade Livre de Direito do Rio de Janeiro. Em 2021 celebra-se cento e trinta anos do início das atividades das duas Faculdades-Livre, embriões da atual FND.

${ }^{3}$ Além da Faculdade de Direito da UFRJ, a Faculdade de Direito da Universidade Federal da Bahia (ex-Faculdade de Direito da Bahia), instalada em 15 de abril de 1891 na cidade de Salvador, também obteve no mesmo ano o título de Faculdade Livre, na forma do art. 420 do Decreto $\mathrm{n}^{\mathrm{O}}$ 1.232- $\mathrm{H}$, precedendo a primeira quanto a data do Ato autorizativo (Decreto $\mathrm{n}^{\mathrm{o}}$ 599, de 17 de outubro). Em 1946, por força do art. $2^{\text {o }}$ do Decreto-lei $n^{\circ}$ 9.155, de 8 de abril, a Faculdade de Direito da Bahia foi incorporada à Universidade da Bahia, criada pelo art. $1^{\circ}$ do referido diploma.
} 
$\mathrm{ano}^{4}$. Embora tenham sido autorizadas a funcionar no mesmo Ato, formalmente, as Faculdades citadas eram instituições distintas, somente ocorrendo a unificação delas em 24 de abril de 1920, com a denominação de Faculdade de Direito do Rio de Janeiro. Aliás, nesse mesmo ano, a Faculdade de Direito do Rio de Janeiro passou a integrar a Universidade do Rio de Janeiro, criada pelo art. $1^{\mathrm{o}}$ do Decreto $\mathrm{n}^{\mathrm{o}}$ 14.343, de 7 de setembro, in verbis: "Ficam reunidas, em 'Universidade do Rio de Janeiro', a Escola Politécnica do Rio de Janeiro, a Faculdade de Medicina do Rio de Janeiro e a Faculdade de Direito do Rio de Janeiro, dispensada esta da fiscalização".

Com apoio no método indutivo, a partir da concepção de Faculdade Livre, organização acadêmica das instituições que originaram a FND, bem como utilização de pesquisas bibliográfica e documental, o trabalho analisa o Decreto $\mathrm{n}^{\mathrm{o}}$ 1.232-H, nos seguintes aspectos: a) os estabelecimentos autorizados a ministrar ensino jurídico; b) a estrutura curricular dos cursos; c) os exames aplicados pelas Faculdades Livres aos discentes; d) o corpo docente; e) a administração e o corpo deliberativo; f) a divulgação da produção científica; g) os graus conferidos aos concluintes.

$\mathrm{O}$ artigo estrutura-se em três seções. A primeira evoca brevemente o Decreto Imperial de 9 de janeiro de 1825, predecessor da Lei de 11 de agosto de 1827, promulgada por Dom Pedro I na forma do art. 69 da Constituição de 1824, sancionando o Decreto da Assembleia Geral4 ${ }^{5}$ sobre a criação de dois cursos jurídicos. Também nesta seção serão postos em relevo o texto da Lei de 11 de agosto no cotejo com alguns traços importantes do Projeto de Regulamento ou Estatutos dos Cursos Jurídicos, elaborado em 1825 pelo Visconde da Cachoeira, mandado aplicar provisoriamente aos novos cursos pelo art. 10 da Lei. A segunda seção marca a transição legislativa após a Lei de 11 de agosto de 1827 até o advento da Reforma Benjamin Constant, em 1891, e as principais alterações

\footnotetext{
${ }^{4}$ Além da Faculdade de Direito da UFRJ, a Faculdade de Direito da Universidade Federal da Bahia (ex-Faculdade de Direito da Bahia), instalada em 15 de abril de abril de 1891 na cidade de Salvador, também obteve no mesmo ano o título de Faculdade Livre, na forma do art. 420 do Decreto $\mathrm{n}^{\circ}$ 1.232-H, precedendo a primeira quanto a data do Ato autorizativo (Decreto $\mathrm{n}^{-}$599, de 17 de outubro). Em 1946, por força do art. 2º do Decreto-lei no 9.155, de 8 de abril, a Faculdade de Direito da Bahia foi incorporada à Universidade da Bahia, criada pelo art. $1^{\circ}$ do referido diploma. ${ }^{5}$ A Constituição de 1824 dispunha no Capítulo IV (Da Proposição, Discussão, Sanção e Promulgação das Leis) do Título IV (Do Poder Legislativo), art. 62, que "Se qualquer das duas Câmaras [dos Deputados e dos Senadores], concluída a discussão, adoptar inteiramente o Projeto, que a outra Câmara lhe enviou, o reduzirá a Decreto, e depois de lido em sessão, o dirigirá ao Imperador em dois autógrafos, assignados pelo Presidente, e os dois primeiros Secretários, pedindo-lhe a sua sanção [...] pela formula seguinte - A Assembleia Geral dirige ao Imperador o Decreto incluso, que julga vantajoso, e útil ao Império, e pede a Sua Majestade Imperial, se digne dar a sua sanção". Com a sanção do Decreto, que ganhava força de lei, o Imperador exercia uma das atribuições do Poder Moderador prevista no art. 101, III, da Constituição.
} 
promovidas neste interregno de mais de sessenta anos (1827-1891), com ênfase na estrutura curricular. A derradeira seção adentra no tema propriamente dito analisando disposições do Decreto $\mathrm{n}^{-}$1.232-H nos sete aspectos acima apontados.

\section{A [RE]CRIAÇÃo dos CURSOS JURídicos PELA Lei 11 DE AGOSTO DE 1827}

Convém registrar que a data em que se comemora o Dia do Advogado, 11 de agosto, é alusiva à criação dos dois primeiros cursos jurídicos no Brasil, um na cidade de São Paulo ${ }^{6}$, à época capital da Província homônima, e o outro na cidade de Olinda ${ }^{7}$, Província de Pernambuco. Todavia, trata-se na verdade de uma "recriação", considerando-se que, em 1825, por Decreto de 9 de janeiro, o Imperador Dom Pedro I, criou provisoriamente um curso jurídico na cidade do Rio de Janeiro, "Corte" e capital do Império, porém ele não foi instalado.

O Decreto, abaixo transcrito em seu inteiro teor, enfatiza as justificativas para a criação do curso jurídico, que podem ser assim sintetizadas: (i) fomentar a educação e instrução públicas; (ii) formar futuros magistrados bacharéis para atuar no País, que deles carecia; (iii) afirmar a independência política do Império, desonerando seus habitantes de buscar o ensino jurídico em Portugal ou em outros países e os inconvenientes decorrentes e (iv) criar o curso jurídico urgentemente, ainda que isoladamente, diante da falta recursos para estabelecimento de Universidades, como previa o art. 179, § 33, da Constituição.

Querendo que os habitantes deste vasto e rico Império, gozem, quanto antes, de todos os benefícios prometidos na Constituição ${ }^{8}$, art. $179 \S 33$, e considerando ser um destes a educação, e pública

\footnotetext{
${ }^{6} \mathrm{O}$ curso de Direito, criado na cidade de São Paulo e instalado em $1^{\circ}$ de março de 1828 no convento de São Francisco, centro da cidade, era mantido pelo governo federal (Cf. art. $1^{\circ}$ do Código das disposições comuns ás instituições de ensino superior dependentes do Ministério da Justiça e Negócios Interiores, aprovado pelo Decreto no 1.159, de 3 de dezembro de 1892). Em 1934, com a criação da Universidade de São Paulo (USP), a Faculdade de Direito de São Paulo passou a integrar a Universidade, criada pelo Decreto estadual no ${ }^{\mathbf{0}}$ 6.283, de 25 de janeiro, como unidade acadêmica (art. $3^{\circ}$, a).

${ }^{7} \mathrm{O}$ curso de Direito, criado na cidade de Olinda/PE e instalado no Mosteiro de São Bento em 15 de maio de 1828, foi transferido para o centro da cidade do Recife em 1854, em cumprimento a autorização contida no art. 286 do Decreto n⿳o 1.134/1853. Tal qual seu congênere de São Paulo, era mantido pelo governo federal. A Faculdade de Direito do Recife, desde 1946, integra a Universidade Federal de Pernambuco (ex-Universidade do Recife) como unidade acadêmica, em razão do art. 2º, n. 1, do Decreto-lei n⿳亠口冋 9.388/46.

${ }^{8} \mathrm{O}$ referido dispositivo da Constituição de 1824 previa que a inviolabilidade dos Direitos Civis e Políticos dos Cidadãos Brasileiros, que tem por base a liberdade, a segurança individual, e a propriedade, é garantida pela maneira seguinte [...] XXXIII. Colégios e Universidades, onde serão ensinados os elementos das Ciências, Belas Letras e Artes.
} 
instrução, o conhecimento de Direito Natural, Público, e das Gentes, e das Leis do Império, afim de se poderem conseguir para o futuro Magistrados hábeis e inteligentes, sendo aliás da maior urgência acautelar a notória falta de Bacharéis formados para os lugares da Magistratura pelo estado de Independência Política, a que se elevou este Império, que torna incompatível ir demandar, como d'antes, estes conhecimentos à Universidade de Coimbra, ou ainda a quaisquer outros países estrangeiros, sem grandes dispêndios, e incômodos, e não se podendo desde já obter os frutos desta indispensável instrução, se ela se fizer dependente de grandes e dispendiosos estabelecimentos de Universidades, que só com o andar do tempo poderão completamente realizar-se: Ei por bem, ouvido o Meu Conselho de Estado, criar provisoriamente um Curso Jurídico nesta Corte e cidade do Rio de Janeiro, com as convenientes Cadeiras e Lentes, e com o método, formalidade, regulamento e instruções, que baixarão assignadas por Estevão Ribeiro de Rezende, do Meu Conselho, Meu Ministro e Secretário de Estado dos Negócios do Império. O mesmo Ministro e Secretário de Estado o tenha assim entendido e o faça executar com os despachos necessários. Paço, 9 de janeiro de 1825, $4^{\underline{0}}$ da Independência e do Império.

Da leitura do ato normativo, percebe-se sua omissão em relação ao currículo do curso e sua organização acadêmica, remetendo às instruções e regulamento a serem baixados. Nesse sentido e complementarmente ao Decreto de 9 de janeiro de 1825, coube ao Visconde da Cachoeira9 ${ }^{9}$ elaborar Projeto para os Estatutos do primeiro curso jurídico ${ }^{10}$, apresentado em 2 de março de 1825 . Não obstante, o curso nunca tenha sido implementado, os Estatutos foram aproveitados, em caráter subsidiário, para os cursos jurídicos criados em 1827, em razão do art. 10 da Lei de 11 de agosto: "Os Estatutos do Visconde da Cachoeira ficarão regulando por ora naquilo em que forem aplicáveis; e se não opuserem à presente Lei. A Congregação dos Lentes [docentes] formará quanto antes uns estatutos completos, que serão submetidos à deliberação da Assembleia Geral".

Se o legislador privilegiou apresentar as justificativas para a criação do curso jurídico em 1825, deixando para sua regulamentação aspectos curriculares,

\footnotetext{
${ }^{9}$ Visconde da Cachoeira (referência à cidade de Cachoeira no recôncavo baiano) era o título nobiliárquico conferido por Dom Pedro I a Luís José de Carvalho e Melo, membro do Conselho de Estado, bacharel em Direito pela Universidade de Coimbra, deputado constituinte em 1823, ministro do Império e magistrado.

${ }^{10} \mathrm{O}$ inteiro teor do Projeto de Estatutos do Visconde da Cachoeira, publicado em sequência à Lei de 11 de agosto, pode ser encontrado na Coleção das Leis do Império do Brasil de 1827. Parte Primeira. Rio de Janeiro: Tipografia Nacional, 1878, p. 7-39.
} 
administrativos e acadêmicos, sentido oposto trilhou a Lei de 1827. Esse diploma é silente quanto aos "considerandos", na premissa de já estarem expostos no Decreto de 1825. O ponto em comum entre os diplomas citados é a indicação do local de instalação - o de 1825 na cidade do Rio de Janeiro, e os de 1827, nas cidades de São Paulo e de Olinda. Por outro lado, a expressão "curso jurídico" é substituída na Lei de 1827 por "cursos de ciências jurídicas e sociais" (art. 1º).

Analisando-se a Lei de 1827, percebe-se que ela incorpora temas contidos no Projeto de Regulamento do Visconde da Cachoeira, embora com modificações ${ }^{11}$, como se demonstrará na seção seguinte.

\subsection{Os Estatutos do Visconde da Cachoeira para os cursos jurídicos vis-à-vis a Lei de} 11 de agosto de 1897

O Regulamento (ou Estatutos) apresentado em 2 março de 1825, assinado pelo Visconde da Cachoeira, estava estruturado em dezenove capítulos, precedidos de Exposição de Motivos. Os dois primeiros não tratavam do curso em si, embora possuíssem relação indireta com ele, haja vista discorrerem, respectivamente, sobre estudos e exames preparatórios para fins de ingresso, exigências explicitadas nos arts. $8^{\circ}$ e 11 da Lei de 11 de agosto. A matriz curricular e o tempo de duração eram contemplados nos capítulos III a VIII, sendo a parte mais importante dos Estatutos, tanto pela riqueza de orientações aos professores como também as justificativas para o ensino das disciplinas, metodologia do ensino e indicações bibliográficas. A ordem de oferta das disciplinas seguia uma sequência natural e progressiva, partindo de conhecimentos propedêuticos até os de ordem técnica e prática, preponderantes a partir do $3^{\mathrm{o}}$ ano. ${ }^{12}$ Os capítulos IX a XIII, XV e XVI discorriam sobre a organização acadêmica (matrículas, exercícios práticos das aulas, forma e aplicação das avaliações, critérios para aprovação e reprovação, requisitos para obtenção dos graus de bacharel e de doutor, férias dos alunos e prêmios em dinheiro por merecimento). Os capítulos XIV, XVII, XVIII e XIX versavam sobre a organização administrativa do curso (Congregação, Direção, hierarquia entre os professores - lentes e substitutos, secretário e outros empregados).

Cabe por em relevo alguns aspectos importantes do documento, começando pelo perfil do egresso proposto pelo Visconde da Cachoeira.

${ }^{11} \mathrm{O}$ inteiro teor da Lei de 11 de agosto de 1827 pode ser encontrado na Coleção das Leis do Império do Brasil de 1827. Parte Primeira. Rio de Janeiro: Tipografia Nacional, 1878, p. 5-7.

12 "O curso completo de direito será de cinco anos, em cada um dos quais se ensinarão as matérias que podem formar um jurisconsulto brasileiro seguindo a ordem mais natural e metódica, a fim de que os estudantes vão como levados por degraus e pela mão até o fim desta carreira". In COLEÇÃO DAS LEIS DO IMPÉRIO DO BRASIL DE 1827. Parte Primeira. Rio de Janeiro: Tipografia Nacional, 1878, p. 16. 
Tendo-se decretado que houvesse, nesta Corte, um curso jurídico para que nele se ensinassem as doutrinas de jurisprudência em geral, a fim de se cultivar este ramo da instrução pública, e se formarem homens hábeis para serem um dia sábios magistrados, e peritos advogados, de que tanto se carece; e outras que possam vir a ser dignos Deputados e Senadores, e aptos para ocuparem os lugares disponíveis e mais empregos do Estado [...]..$^{13}$

Percebe-se que o egresso dos cursos jurídicos seria um bacharel que atuaria não só como magistrado (a única profissão jurídica mencionada nas justificativas da Lei de 9 de janeiro de 1825), mas também como advogado, político ou servidor público. Assim, o curso serviria para formar mão de obra qualificada para postos e cargos de destaque no Império. Isso reforça o caráter elitista do curso, voltado às necessidades da aristocracia e da alta burguesia, os segmentos da sociedade que tinham acesso à educação na época.

Os Estatutos privilegiavam a metodologia de ensino que aliasse a teoria à prática, especialmente pelo conteúdo das disciplinas ("cadeiras") do $5^{\circ}$ ano, todo voltado à análise de doutrina e legislação aplicada à prática, com apoio na hermenêutica.

Haverá neste ano também duas cadeiras. O Professor da $1^{\text {a }}$ se ocupará em explicar por análise alguns textos; e principiando por duas das leis romanas, que mais célebres forem ou por sua doutrina, ou pela aplicação que poderem ter no foro pátrio, passará depois a analisar alguma decisão pátria do corpo das ordenações, ou algumas leis. Nestas análises mostrará a origem jurídica da matéria; a justa combinação de princípios elementares de direito natural que lhe são relativas; a jurisprudência análoga das nações polidas, c aplicação que têm no foro nacional, acostumando assim os ouvintes não só a chegarem ao perfeito conhecimento das leis pelo método analítico, como a escreverem pelo mesmo método as dissertações, c fazendo-lhes adquirir a prática para as alegações de ponderação, que houverem de fazer no foro e causas célebres. Ensinará também a hermenêutica jurídica ou arte de interpretar as leis, para que conhecendo os ouvintes as diversas espécies de interpretações, possam perfeitamente usar delas nos textos difíceis ou complicados, e estabelecerá os limites da que toca ao jurisconsulto, advogado ou magistrado. [...].

O Professor da segunda cadeira deste ano ocupar-se-á na exposição do uso prático de direito e explicará por conseguinte

${ }^{13}$ Idem, p. 7-8. 
todas as matérias que lhe são relativas a fim de que os estudantes fiquem certos da maneira, por que praticamente hão de usar das doutrinas, que aprenderem no estudo das leis pátrias. ${ }^{14}$

O estudo e conhecimento da jurisprudência e sua aplicação às questões forenses tem papel preponderante na metodologia de ensino dirigida aos professores responsáveis pelas disciplinas do terceiro e quarto anos, como fica patente neste trecho do documento:

Sendo regulados os estudos do Curso Jurídico em ordem a formar-se um consumado jurisconsulto brasileiro, e devendo consistir a perícia deste não só em saber os preceitos da jurisprudência, mas também na judiciosa prática e aplicação dos mesmos preceitos, como convém que se vão, desde logo afazendo os estudantes ao hábito de aplicaram os conhecimentos teóricos à prática de advogar e de julgar. Por este motivo devem os Professores de ambos estes anos [referindo-se ao terceiro e quarto ano] mostrar aos seus discípulos o uso prático que têm no foro as doutrinas que ouviram, e expender as diversas maneiras, por que se empregam, tanto no foro civil, como no criminal. ${ }^{15}$

Embora o Imperador tenha determinado a aplicação provisória dos Estatutos do Visconde da Cachoeira aos novos cursos, a redação do art. 10 da Lei de 1827 impunha-lhe caráter subsidiário ("naquilo em que forem aplicáveis; e se não opuserem à presente Lei"). Cabe, então, analisar quais eram as divergências entre os Estatutos e a Lei, não sem antes seremapontadas as convergências. São elas:

1) prazo de duração de cinco anos (Estatutos, capítulo III; Lei. art. $1^{\mathrm{o}}$ );

2) previsão na estrutura administrativa de 1 (um) porteiro e outros empregados (Estatutos,capítulo XIX, Lei, art. $6^{\circ}$ );

3) requisitos para ingresso exigiam idade mínima, estudos preparatórios e aprovação nos exames (Estatutos, capítulo II, Lei, arts. $8^{\mathrm{o}}$ e 11); e

4) concessão de dois graus aos concluintes, o de bacharel e o de doutor $^{16}$ (Estatutos, capítulosXII e XIII, Lei, art. 9º).

\footnotetext{
${ }^{14}$ Idem, p. 28-29.

${ }^{15}$ Idem, p. 28.

${ }^{16} \mathrm{O}$ grau de bacharel em ciências jurídicas e sociais era conferido aos estudantes concluintes do $5^{\underline{0}}$ ano, aprovados nos exames orais e na dissertação sobre ponto sorteado (cf. Estatutos, capítulo XII, item $6^{\circ}$ ). Sobre a avaliação da dissertação, discorre o documento: "Este ato deve ser o mais rigoroso, porque é o último que faz o estudante para ser Bacharel formado, e merecer o
} 
5)

Passando-se aos aspectos divergentes, inicia-se pela matriz curricular do curso, apresentada nas versões dos Estatutos e da Lei de 1827 na tabela abaixo:

\begin{tabular}{|c|c|}
\hline $\begin{array}{l}\text { Estatutos do Visconde da Cachoeira } \\
10 \text { cadeiras }\end{array}$ & $\begin{array}{l}\text { Lei de } 11 \text { de agosto de } 1827 \\
9 \text { cadeiras }\end{array}$ \\
\hline $\begin{array}{l}1^{o} \text { ano: direito natural, direito público } \\
\text { (1) einstitutas do direito romano (2). }\end{array}$ & $\begin{array}{l}1^{\circ} \text { ano: direito natural, direito público, } \\
\text { análise } \\
\text { de Constituição do Império, direito } \\
\text { dasgentes e diplomacia (1) }\end{array}$ \\
\hline $\begin{array}{l}2^{o} \text { ano: direito das gentes e diplomacia } \\
\text { (3) } \\
\text { direito comercial e marítimo (4) }\end{array}$ & $\begin{array}{l}2^{\circ} \text { ano: as mesmas matérias do } 1^{\circ} \text { ano } \\
\text { (2) e } \\
\text { direito público eclesiástico }{ }^{17}(3)\end{array}$ \\
\hline $\begin{array}{l}3^{0} \text { ano: direito público nacional, } \\
\text { incluindo o direito criminal e o } \\
\text { eclesiástico (5) e direito } \\
\text { privado nacional (6) }\end{array}$ & $\begin{array}{l}3^{\text {o }} \text { ano: direito civil pátrio (4) e direito } \\
\text { criminal pátrio com a teoria do processo } \\
\text { criminal (5) }\end{array}$ \\
\hline $\begin{array}{l}4^{\mathrm{o}} \text { ano: continuação do direito civil e } \\
\text { criminal } \\
\text { pátrio (7) economia política (8) }\end{array}$ & $\begin{array}{l}4^{\circ} \text { ano: continuação do direito civil pátrio } \\
(6) \\
\text { e direito mercantil e marítimo ( } 7)\end{array}$ \\
\hline $\begin{array}{l}5^{\circ} \text { ano: doutrina e legislação aplicadas } \\
\text { à prática e hermenêutica jurídica (9) } \\
\text { prática do } \\
\text { direito e processo (10) }\end{array}$ & $\begin{array}{l}5^{\mathrm{o}} \text { ano: economia política }(8) \text { e teoria e } \\
\text { práticado processo pátrio }(9)\end{array}$ \\
\hline
\end{tabular}

respectivo título, com o qual pode exercer os mais importantes empregos do Estado". O grau de doutor era complementar ao de bacharel e facultativo, exigindo defesas públicas de teses, porém era o único que habilitava ao exercício da docência no curso ("Lente"). A Lei de 1827 remetia aos Estatutos quanto aos requisitos para sua obtenção e esse assim dispunha no capítulo XII, item 1을 "Se algum estudante jurista quiser tomar o grau de Doutor, depois de feita a competente formatura, e tendo merecido a aprovação nemine discrepante [sem discrepância, por unanimidade], circunstância esta essencial, defenderá publicamente várias teses escolhidas entre as matérias, que aprendeu no Curso Jurídico, as quais serão primeiro apresentadas em Congregação; e deverão ser aprovadas por todos os Professores. O Diretor e os Lentes em geral assistirão a este ato, e argumentarão em qualquer das teses que escolherem. Depois disto assentando a Faculdade, pelo juízo que fizer do ato, que o estudante merece a graduação de Doutor, lhe será conferida sem mais outro exame, pelo Lente que se reputar o primeiro, lavrando-se disto o competente termo em livro separado, e se passará a respectiva carta" (Idem, p. 34-35).

${ }_{17}$ A cadeira de direito eclesiástico foi suprimida dos cursos jurídicos em 1890 pelo Decreto $\mathrm{n}^{\mathrm{o}}$ 1.036-A, de 14 de novembro de 1890, sob justificativa de que, com a Proclamação da República, houve a separação da Igreja do Estado e, com isso, teriam desaparecido os motivos que determinavam o estudo da disciplina. 
A tabela permite verificar que a razão do quantitativo de cadeiras ser menor no currículo do curso criado pela Lei de 1827 ( 9 ao invés de 10) se dá pela supressão do estudo das institutas do direito romano, segunda cadeira do $1^{\underline{0}}$ ano, na versão projetada pelos Estatutos. Assim justificou o Visconde da Cachoeira a inclusão do direito romano: "Como este tem servido de base à maior parte dos códigos civis das nações modernas, e muito dele aproveitaram as compilações das leis que o regem, deve ter um conhecimento, bem que elementar, deste direito com alguma extensão e profundidade". Todavia, em razão da determinação contida no art. 10 da Lei, em caso de colidência prevalecia esta em detrimento dos Estatutos. Haviam também diferenças pontuais entre a ordem de oferta no curso de algumas disciplinas (v.g. direito comercial e marítimo e economia política, que aparecem nos dois currículos, mas em anos diversos). Na matriz curricular contida na Lei de 1827 também é suprimido o estudo da doutrina e legislação aplicadas à prática e hermenêutica jurídica, cadeira contida no $5^{\underline{0}}$ ano do curso. Em compensação, o direito público eclesiástico é alçado à condição de cadeira independente do direito público e natural.

As demais diferenças no cotejo entre a Lei de 1827 e os Estatutos são as seguintes:

1) Para a regência das cadeiras, os Estatutos (capítulo XVIII, item $5^{\circ}$ ) previa quantidade de Lentes proprietários (professores titulares) idêntica ao número de cadeiras e, adicionalmente, três lentes substitutos. A Lei, a seu turno, determinou no art. $2^{\underline{o}}$ a nomeação de cinco lentes substitutos e nove lentes titulares.

2) De acordo com o capítulo XVIII, item 1으, dos Estatutos, os Professores do curso jurídico eram contemplados com todas as honras e prerrogativas de que gozam os da Universidade de Coimbra. A Lei rechaçou tal orientação, mas equiparou o ordenado e as honras dos lentes aos dos desembargadores dos Tribunais da Relação (art. $3^{\circ}$ ).

3) O secretário do curso, nos Estatutos, era um empregado com atribuições próprias do cargo (capítulo XIX); quem desempenhava esta função pela Lei de 1827 era um dos lentes substitutos, que recebia uma gratificação mensal (art. $5^{\circ}$ ).

4) A idade mínima para ingresso nos cursos jurídicos era de 16 anos, segundo o capítulo I, item 1ํㅡㄹ dos Estatutos; na Lei essa idade era de 15 anos, nos termos do art. $8^{\circ}$.

5) Nos Estatutos (capítulo I, item $2^{\circ}$ ), os exames preparatórios para os cursos jurídicos contemplavam seis matérias (latim, francês, retórica, aritmética, geometria e filosofia racionale moral); a Lei de 1827, contemplava cinco matérias, pois excluiu a 
aritmética (art. $8^{\circ}$ ).

6) Enquanto os Estatutos indicavam os compêndios a serem utilizados para o ensino das matérias, a Lei em seu art. $7^{\mathbf{0}}$ permitia que os Lentes escolhessem os compêndios da sua profissão, ou os elaborassem, não existindo já feitos, conferindo aos seus autores o privilégio exclusivo da obra, por dez anos. Os compêndios deveriam ser previamente aprovados pela Congregação.

Por fim, cumpre apontar disposições inéditas na Lei de 1827, como a fixação de remuneração para os lentes (titulares e substitutos), tempo de serviço de vinte anos para jubilamento com provento integral (arts. $3^{\mathrm{o}}$ e $4^{\mathrm{o}}$ ) e a fixação de remuneração para os secretáriose porteiros (art. $5^{\mathrm{o}}$ e $\left.6^{\mathrm{o}}\right)$.

\section{Alterações Legislativas POSTERIORes À Lei $\mathbf{N}^{\circ} 11$, DE AGOSTO DE 1827 (1827-1891)}

A partir da instalação dos cursos em 1828, até o advento do Decreto no ${ }^{0}$ 1.232- $\mathrm{H}$, de 1891, marco legal para a criação da FND, o ensino jurídico passou por várias alterações legislativas. Nesta seção serão apresentadas algumas delas para efeito de apresentação ao leitor de aspectos comparativos com o Decreto $\mathrm{n}^{\mathrm{o}}$ 1.232-H.

A despeito de o art. 10 da Lei de 1827 ter determinado que os Estatutos do Visconde da Cachoeira regulassem provisoriamente os cursos jurídicos até que a Congregação dos Lentes aprovassem novos e os submetessem à deliberação da Asembleia Geral, somente em 7 de novembro de 1831, a Regência, em Nome do Imperador Dom Pedro II, sancionou a Resolução da Assembleia Geral que aprovou, provisoriamente, novos estatutos. Doravante, ficaram revogados os Estatutos do Visconde de Cachoeira como regulamento para a Lei de 1827.

\subsection{Decreto Regencial de 7 de novembro de 1831}

Os Estatutos de 1831, que denominaram os cursos jurídicos de Academia Jurídica, guardaram uma estrutura parecida com seus antecessores, embora tenham passado a tratar de temas inéditos como a solenidade para obtenção do grau de doutor ${ }^{18}$, polícia das aulas e biblioteca (capítulos X, XI e XVI, respectivamente), bem como a criação de capítulos específicos para tratar do grau de bacharel (capítulo VIII), regras para provimento de novos lentes e concursos para esse fim (capítulos XIV e XV).

Iniciam-se os Estatutos pelos exames preparatórios e habilitações para matrícula (capítulo I, fusão dos dois primeiros capítulos dos Estatutos

\footnotetext{
18 A cerimônia de doutoramento, consistia, em síntese, na recepção do doutorando por seu padrinho, escolhido dentre um dos lentes, e acompanhamento até a sala onde se dava a imposição do grau de doutor pelo diretor na presença de todos os lentes, ocasião em que o novo doutor prestava juramento, recebia o anel de seu padrinho e este proferia discurso de exortação do apadrinhado.
} 
precedentes), prosseguem tratando do procedimento de matrícula dos estudantes - que nesses Estatutos precedem a grade curricular (capítulo III). São criadas as Aulas Menores, tema do capítulo II, destinadas ao estudo das matérias dos exames preparatórios exigidos para ingresso nos cursos jurídicos, que passaram a ser incorporadas à organização acadêmica dos cursos de Direito, ministradas por professores externos sob a fiscalização do diretor dos cursos. O capítulo IV cuidou da grade curricular, respeitando o tempo de duração do curso e a distribuição das disciplinas por ano, previstos no art. $1^{\mathrm{o}}$ da Lei de 1827. Tratam da organização acadêmica, além dos já citados capítulos III e IV, os capítulos V (exercícios práticos das aulas), VI (exames), VII (critérios de avaliação), IX (grau de doutor), XII (prêmios), XIII (férias). Quanto a organização administrativa, foram mantidas disposições quanto a Congregação, diretor, lentes, secretários e empregados (capítulos XVII, XVIII, XIX e XX, respectivamente).

\subsection{Decretos nos 1.134/1853 e 1.386/1854 (Reforma Couto Ferraz)}

Os Estatutos baixados pelo Decreto de 1831 vigoraram até 1853, quando foram substituídos por novos em razão da promulação do Decreto no 1.134 , de 30 de março desse ano. Antes desse ano, em 1851, pelo Decreto $n^{\circ}$ 608, de 16 de agosto, a Assembleia Geral Legislativa autorizou o governo a dar novos Estatutos aos cursos juridicos (art. $1^{\circ}$ ), assim como a criar duas novas cadeiras, uma de direito administrativo e outra de direito romano (art. $2^{\mathrm{o}}$ ), restabelecendo, quanto a essa, a proposta contida nos Estatutos do Visconde da Cachoeira.

O Decreto $\mathrm{n}^{\mathrm{o}} 1.134$ teve curta vigência, sendo substituído pelo Decreto $\mathrm{n}^{\mathrm{o}} 1.386$, de 28 de abril de 1854, conhecido como Reforma Couto Ferraz, em alusão a seu elaborador o advogado e político Luiz Pedreira do Couto Ferraz, Visconde do Bom Retiro. Não obstante, o primeiro diploma tem uma importância histórica notável, pois foi a partir dele que os cursos, até então denominados "Academias Jurídicas", passaram a ser constituídos em Faculdades de Direito, designando-se cada uma pelo nome da cidade em que tem ou possa ter assento (art. $1^{\stackrel{o}{ })}$. Os estatutos passaram a ser estruturados em Títulos (Organização da Instituição, Regime Acadêmico e Empregados Acadêmicos), esses divididos em Capítulos, subdivididosem Seções.

Em relação à matriz curricular, o Decreto implementou a determinação do Decreto $\mathrm{n}^{\mathrm{o}}$ 608, inserindo a cadeira de direito romano no $1^{\mathrm{o}}$ ano, nos termos do que propôs em 1825 o Visconde da Cachoeira, e o direito administrativo no $5^{\mathbf{o}}$ ano, que passou a ter três cadeiras. Com isso, o total de cadeiras passou de nove para onze. Alguns ajustes pontuais foram feitos, como a análise da Constituição, inserida no $1^{\mathrm{o}}$ ano, foi transferida para o $5^{\mathrm{o}}$ ano, retornando ao $1^{\mathrm{o}}$ ano com o Decreto $\mathrm{n}^{\mathrm{o}}$ 1.386; agregou-se a hermenêutica jurídica e aplicação das leis à cadeira de direito e prática processual no $5^{\mathrm{o}}$ ano; o direito público eclesiástico passou a abranger o direito eclesiástico pátrio. $\mathrm{O}$ ensino do direito civil pátrio deveria ser feito analítica e comparativamente com o direito romano, outra proposta contida 
nos Estatutos de 1825; agregou-se ao ensino do direito criminal o direito militar. Foram mantidos os cargos de lentes e substitutos, alterando-se a denominação de "lentes proprietários" para "lentes catedráticos".

Os novos Estatutos preservaram os graus de bacharel e doutor conferidos pelas Faculdades, porém o art. 6o esclarecia que o grau de Bacharel em Direito era sufficiente para os empregos que exigiam habilitações acadêmicas. O grau de doutor somente era necessário para os casos em que o exigissem disposições especiais legislativas ou regulamentares. Os arts. $7^{\circ}$ a $9^{o}$ descreviam os exames adicionais para obtenção do grau de doutor, denominados "conclusões magnas", consistente na apresentação e defesa pública de teses, cinco artigos e uma dissertação, cujo procedimento era detalhado no capítulo VI do Título II. O Decreto $\mathrm{n}^{\mathrm{o}} 1.386$ simplificou o procedimento das "defesas de teses", expressão que substituiu as conclusões magnas.

Um ponto de destaque deste Decreto é a quantidade de artigos. A título de comparação, o Decreto de 1831 continha 154 artigos e o de 1853, 290 artigos. Em linhas gerais, os temas continuam os mesmos (habilitações, matrículas, exercícios, disciplina acadêmica, exames, empregados, direção, congregação, lentes, etc), todavia o texto é carregado de minúcias e prcedimentos complexos e solenes, como o provimento das vagas de lentes e realização dos concursos, comprendendo seis seções do capítulo V (arts. 37 a 69).

O Decreto $\mathrm{n}^{\mathrm{o}}$ 1.386/1854 continha apenas 164 artigos, número muito próximo da quantidade do Decreto de 1831, embora albergasse os mesmos temas contidos no Decreto revogado. Contudo, essa redução era aparente, pois o art. 21, § 3º, previa que a Congregação dos Lentes deveria organizar, no prazo de dois meses da publicação dos Estatutos, Regulamento complementar para a boa execução deles, tomando por base as respectivas disposições e submeter à aprovação do Governo. E assim foi feito, de modo que o Decreto $\mathrm{n}^{\mathrm{o}}$ 1.568, de 24 de fevereiro de 1855, aprovou o Regulamento Complementar aos Estatutos. Esse Regulamento, com 262 artigos, esmiuçou as matérias contidas nos três Títulos dos Estatutos.

\subsection{Decreto $n^{-0}$ 3.454, de 26 de abril de 1865 (Reforma José Liberato Barroso)}

Os estatutos para as Faculdades de Direito baixados com o Decreto no 3.454 têm uma curiosidade - nunca entraram em vigor. A razão para tal afirmativa se prende a dois fatos: $1^{\underline{9}}$ ) ausência de autorização legislativa para a edição do Decreto e $2^{\circ}$ ) falta de Regulamento complementar para sua execução, condição imposta pelo art. 138 do Decreto para suaexecução provisória.

Os estatutos dos cursos, academias e faculdades de Direito, conforme a ordem cronológica de designações que receberam, deviam ser aprovados pela Assembleia Geral Legislativa com sanção do Imperador para que tivessem força de lei, tal qual ocorreu com a Lei de 11 de agosto de 1827. Em 1851, o governo recebeu autorização da Assembleia para editar Decreto com novos estatutos. Nesse sentido, o Decreto $n^{0} 1.134$ era válido e regular, pois sua edição tinha por 
base o Decreto no 608. Ocorre que esta autorização era ad hoc, não se estendendo a futuros estatutos após a aprovação definitiva pelo Corpo Legislativo, o que ocorreu em 1854 com o Decreto $\mathrm{n}^{-}$1.386. Quaisquer estatutos que viessem a substituir aqueles aprovados provisoriamente em 1853 e, definitivamente, em 1854 necessitavam de novaautorização assemblear ou aprovação por ela.

A bem da verdade, o governo imperial invocou no Decreto $n^{0} 3.454$ a "autorização concedida pelo Decreto no 714, de 19 de setembro de 1853". Entretanto, esta autorização não tinha por objetivo permitir que novos estatutos fossem elaborados após 1854. Está consignado no Decreto no 714 que o governo ficou autorizado a "realizar o aumento da despesa que for necessaria para a execução provisória dos novos Estatutos das Faculdades de Direito e de Medicina, publicados com os Decretos no 1.134 e 1.169, de 30 de março e 7 de maio deste ano". Também foi concedida autorização para que os estatutos provisórios sofressem as alterações que o governo julgasse convenientes "até que sejam eles definitivamente aprovados pelo Corpo Legislativo", fato que se deu em 1854 e, com isso, esgotou-se a autorização. Todavia, a pretensa "autorização" serviu de base para que o ministro e advogado José Liberato Barroso, em abril de 1865, apresentasse novos estatutos de sua autoria e os tivesse aceito pelo imperador. Verificada a irregularidade, a Assembleia Geral decidiu suspender a execução do Decreto em junho de 1865, por vício de iniciativa. A segunda razão para a inexecução do Decreto reside na necessidade de sua regulamentação diante da disposição contida no já citado art. 138 e no art. 128, in verbis: "Para boa execução destes Estatutos o Governo organizará um Regulamento Complementar cujas disposições servirão de base às Instruções que as Congregações tiverem de propor". Esse regulamento nunca foi editado e, com isso, permaneceram em vigor os estatutos de 1854 com o regulamento complementar baixado no ano seguinte (cf. seção 3.2).

A despeito do que foi exposto e para efeito de comparação na seção 4 com o Decreto $\mathrm{n}^{\mathrm{0}}$ 1.232-H/1891, a Reforma Liberato Barroso trouxe uma novidade: as Faculdades de Direito passaram a oferecer dois cursos, cada um composto por uma seção de ensino - Ciências Jurídicas e Ciências Sociais. Cada curso conferia grau distinto a seus concluintes. A primeira seção, cujo curso durava 4 anos, tinha 8 cadeiras (direito natural privado e público, direito romano, análise da Constituição do Império, direito criminal, direito civil pátrio, direito comercial e marítimo, teoria e prática do processo e direito eclesiástico). A segunda seção, de Ciências Sociais, tinha o curso com menor duração -3 anos - e apenas 6 cadeiras (direito natural privado e público, análise da Constituição, direito internacional e diplomacia, direito administrativo, economia politiza e direito eclesiástico). A disciplina direito eclesiástico, comum aos dois cursos, era de frequência facultativa.

Por efeito da criação de duas seções, as Faculdades, que até então conferiam dois graus - bacharel em Ciências Jurídicas e Sociais e doutor em Ciências Jurídicas e 
Sociais, passariam a conferir três graus: bacharel em Ciências Jurídicas, bacharel em Ciências Sociais e doutor em Ciências Jurídicas e Sociais. Os dois primeiros graus seriam conferidos aos aprovados em todas as matérias da seção na qual estivessem matriculados, já o grau de Doutor seria conferidoàquele que cursasse as duas seções, fosse aprovado em todas as matérias e defendesse as teses.

\subsection{Decreto $n^{-} 7.247$ de 19 de abril de 1879 (Reforma Leôncio de Carvalho)}

Na sequência cronológica de estatutos das Faculdades de Direito surge o Decreto $\mathrm{n}^{\mathrm{o}}$ 7.247, de 19 de abril de 1879, idealizado pelo advogado e ministro Carlos Leôncio de Carvalho.

Primeiramente, faz-se mister destacar que o referido Decreto não tinha por objetivo apenas reorganizar o ensino jurídico, possuindo escopo muito mais ambicioso - reformar o ensino primário e secundário no município da Corte (atual cidade do Rio de Janeiro) e o superior em todo o Império. A rigor, o Decreto continha disposições gerais para todos os segmentos do ensino, sem revogar os regulamentos de instrução ou estatutos existentes, como se percebe pelo trecho do seu preâmbulo "que os regulamentos da Instrução primária e secundária do município da Corte, os dos exames de preparatórios nas províncias, e os estatutos das Faculdades de Direito e de Medicina e da Escola Politécnica se observem de acordo com as seguintes disposições". A partir dessa conclusão, permaneciam em vigor as disposições do Decreto n⿳0 $1.386 / 1854$ e seu regulamento aprovado pelo Decreto $\mathrm{n}^{\mathrm{o}} 1.568 / 1855$, na parte que não colidissem com o novel Decreto.

A marca principal da Reforma Leôncio de Carvalho foi a instituição do ensino superior "completamente livre" em todo o Império, e, para os ensinos primário e secundário, apenas no município da Corte (art. $1^{\circ}$ ). A única ressalva a essa plena liberdade era a inspeção obrigatória a que estavam sujeitos os professores que mantiverem aulas ou cursos livres para garantir "as condições de moralidade e higiene". Para tanto, a pessoa obrigada por lei deveria comunicar ao inspetor geral da instrução pública, sob pena de multa, dentro de um mês da abertura dos cursos, o local em que eles funcionam, se recebem alunos internos, semi-internos ou somente externos, as condições da admissão ou matricula, o programa do ensino e os professores encarregados deste, bem como prestar todas as informações que lhes fossem requisitadas pelas autoridades competentes e franquear os estabelecimentos à visita das mesmas autoridades, sempre que se apresentarem para examina-los ou assistir às lições e exercícios.

$\mathrm{O}$ art. 20 do Decreto, em aditamento ao art. $1^{\circ}$, autorizava qualquer pessoa, mediante prévia inscrição na secretaria de cada Faculdade, em épocas determinadas, a prestar exame, de qualquer número de matérias do respectivo curso nos estabelecimentos de instrução superior dependentes do Ministério do Império, desde que comprovassem aprovação nas matérias preparatórias ou nas matérias antecedentes do curso, mesmo sem matrícula prévia nele ou frequência às aulas (cf. art. 20, $\S 6^{\circ}$ ). Estas disposições revelam que o ensino livre poderia ser 
doméstico, em estabelecimentos privados ou até mesmo em estabelecimentos oficiais, desde que as respectivas Congregações concedessem salas para cursos livres das matérias ensinadas nos mesmos estabelecimentos (cf. art. 22). Em qualquer caso, deveria haver um responsável nestes cursos que se submetesse à fiscalização governamental e prestasse as informações exigidas no Decreto. A qualquer momento, os alunos poderiam aceder ao ensino superior cumpridas as exigências do referido art. 20. Os exames livres de quaisquer matérias ensinadas sem alguma Faculdade davam direito à matricula para o estudo das que se seguirem imediatamente na ordem do respectivo programa, e os de todas ao grau conferido pela mesma Faculdade com as prerrogativas a ele inerentes (cf. art. 20, § $8^{\circ}$ ). Em suma, a Faculdade de Direito de São Paulo, por exemplo, poderia conferir o grau de bacharel a um homem que nunca tivesse sido aluno, mas que tenha sido aprovado nos exames de todas as disciplinas da grade.

$\mathrm{O}$ art. 21 reconhecia os cursos livres, considerados como "associação de particulares para a fundação de cursos onde se ensinem as matérias que constituem o programa de qualquer curso oficial de ensino superior", sendo vedada a intervenção do governo na organização dessas associações. Aos cursos livres que cumprissem as exigências do parágrafo $1^{\circ}$ (funcionamento regular por 7 anos consecutivos e ter, pelo menos, 40 de seus ex-alunos obtido grau acadêmico do curso oficial) poderia ser concedido o título de Faculdade Livre, com todos os privilégios e garantias de que gozasse a Faculdade oficial. Sem embargo, a concessão do título dependia daaprovação do Poder Legislativo.

Uma vez obtido o reconhecimento da associação particular como Faculdade Livre, ela tinha as mesmas prerrogativas das oficiais ${ }^{19}$, porém com autonomia administrativa e financeira. Por conseguinte, ela podia conferir aos seus alunos os graus acadêmicos concedidos pelas Faculdades do Estado, desde que eles tivessem as aprovações exigidas pelos estatutos destas para a colação de grau. Os exames nas Faculdades Livres deveriam ser prestados em conformidade com as leis, decretos e instruções que regulassem os das Faculdades oficiais e valeriam para a matrícula nos cursos destas. O governo deveria nomear anualmente comissáriospara assistir a esses exames e informar sobre a sua regularidade.

Nota-se que o objetivo do Decreto era quebrar o monopólio do ensino oficial (no caso do ensino jurídico, das Faculdades de São Paulo e do Recife, as únicas existentes) e ampliar a oferta de vagas e acesso à educação sem onerar o poder público. Não se trata de uma "privatização" do ensino, haja vista que nenhuma instituição oficial foi entregue à administração ou mantença de particular. Entretanto, a medida abria a possibilidade de aumento do número de

\footnotetext{
${ }^{19}$ Os parágrafos do art. 21 deixam patente outros aspectos da equiparação das Faculdades Livres aos estabelecimentos oficiais, tais como o ensino de, pelo menos, todas as matérias que constituírem o programa da Faculdade oficial correspondente e a existência de uma Congregação de Lentes em cada Faculdade livre, com as atribuições que lhe forem dadas pelo respectivo regimento.
} 
faculdades de direito sem que para isto o governo tivesse que aumentar despesas. O fato é que somente após a permissão de criação de cursos e estabelecimentos "livres" novas Faculdades foram criadas, porém com o advento da proclamação da República e a partir do Decreto $\mathrm{n}^{\mathrm{o}}$ 1.232-H, de 1891. A Reforma Leôncio de Carvalho manteve a orientação da Reforma anterior de 1865, baixada pelo Decreto no 3.454, quanto a cisão dos currículos dos cursos jurídicos em duas seções (cf. seção 3.3), porém indicou as habilitações para os bacharéis de cada seção. Dessa forma, alterando-se o modelo da legislação de 1854 ora vigente, o art. 23 do Decreto $n^{0}$ 7.247/1879 dispunha que as Faculdades de Direito serão divididas em duas seções, ambas com a mesma duração: a das ciências jurídicas e a das ciências sociais. A primeira seção englobava 9 matérias (e não 8 como na reforma anterior): direito natural, direito romano, direito constitucional (designação que substitui a análise da constituição do império), direito eclesiástico, direito civil, direito criminal, medicina legal (matéria inédita), direito comercial e teoria do processo criminal, civil e comercial com uma aula prática. A seção das ciências sociais reunia também 9 matérias (ao invés de 6): direito natural, direito público universal, direito constitucional, direito eclesiástico, direito das gentes, diplomacia e história dos tratados, direito administrativo, ciência da administração e higiene pública, economia política, ciência das finanças e contabilidade do Estado (matéria inédita). Algumas matérias eram ministradas em mais de uma disciplina ("cadeira") e, nesse caso, o ensino de uma seria a continuação do da outra. Estavam nesta situação direito civil, direito criminal, direito comercial, direito administrativo, teoria e pratica do processo criminal, civil e comercial. Em relação à metodologia de ensino, o art. 23, § 50, exigia que o estudo do direito constitucional, criminal, civil, comercial e administrativo fosse sempre acompanhado da comparação da legislação pátria com a dos povos cultos, regra mantida no Decreto n⿳0 9.360/1885 (cf. seção 3.5).

Como consequência da divisão do curso em seções de ensino, as faculdades (oficiais e livres) poderiam conferir os graus de bacharel em ciências sociais ou em ciências jurídicas. $\mathrm{O}$ primeiro habilitava o concluinte para a funções no serviço público, como a de adido de legações (diplomata), praticantes e amanuenses das Secretarias de Estado e mais repartições públicas. Já o segundo, a seu turno, habilitava o concluinte para a advocacia e a magistratura.

Embora o Decreto no 7.247/1879 dependesse de regulamentos (para os ensinos primário e secundário) e estatutos (no caso dos cursos superiores) para sua plena execução (art. 26), o art. 28 permitiu sua execução provisória desde já, na parte que não dependesse de regulamento e que o governo julgasse conveniente, orientação diversa da adotada pelo art. 138 do Decreto nº 3.454/1865.

3.5 Decretos $n^{-} 9.360$ e $n^{0}$ 9.522, respectivamente, de 17 de janeiro e 28 de novembro de 1885

Em 1885, os estatutos dos cursos jurídicos sofreram mais uma alteração pelo 
Decreto $\mathrm{n}^{-}$9.360, de 17 de janeiro, conhecida por Reforma Franco de Sá, em referência ao magistrado e ministro imperial Filipe Franco de Sá. Todavia, a reforma teve brevíssima duração, pois no mesmo ano o Decreto teve sua execução suspensa por outro - Decreto no 9.522, de 28 de novembro. Portanto, até o final do Império e mesmo com a proclamação da República, até 1891, permaneceram em vigor as disposições do Decreto nº 7.247/1879.

Destaca-se que a Reforma Franco de Sá manteve a cisão do curso de Direito em dois, o de ciências jurídicas e o de ciências sociais (art. $2^{\underline{o}}$ ), cada um conferindo grau distinto (art. 295), além do grau de doutor para quem fosse aprovado nos dois cursos e defendesse as teses, na linha inaugurada pelo Decreto $n^{0} 3.454 / 1865$ e com as mesmas habilitações do estatuto anterior (art. 296). Também foram preservadas as Faculdades e cursos livres (Cf. Decreto no 9.360/1885, arts. 19, 39 e Capítulo X - Do Ensino Particular nas Faculdades).

Destacam-se nestes comentários duas inovações nos estatutos de 1885: a criação de duas novas matérias, uma em cada curso, e a instituição da vitaliceidade dos lentes catedráticos e substitutos.

Nos termos dos arts. 3으, 4º $5^{\circ}$ e $6^{\circ}$, os cursos de ciências jurídicas e de ciências sociais eram compostos de 11 matérias e 22 cadeiras agrupadas, respectivamente, em 6 e 5 séries anuais de exames. As matérias do curso jurídico eram: direito natural, direito romano, direito constitucional, direito eclesiástico, direito civil, direito criminal, medicina legal, direito comercial, história do direito nacional (inédita), teoria e prática dos processos civil e comercial e teoria e prática do processo criminal (desdobrada da matéria de teoria dos processos criminal, civil e comercial) com hermenêutica jurídica. As matérias do segundo curso eram: direito natural, direito público universal, direito constitucional, direito eclesiástico, direito das gentes, diplomacia e história dos tratados, ciência da administração e direito administrativo, higiene pública, economia política, ciência das finanças e contabilidade do Estado e noções de legislação comparada sobre o direito privado (matéria inédita).

Os lentes cathedráticos e substitutos passaram a ser vitalícios e, como tal, só poderiam ser demitidos se fossem condenados por crime cuja pena cominasse perda do emprego, a de galés ou de prisão com trabalho, ou por crime de estupro, rapto, adultério, furto ou outros considerados infamantes ou ofensivos da moral (art. 47). Tal vitaliciedade só foi abolida com o advento da Constituição de 1967 (art. 177), assegurados os direitos dos professores catedráticos nomeados até o início de sua vigência.

\section{A PRIMEIRA REFORMA DO ENSINO JURÍDICO NA REPÚBLICA: DECRETO № 1.223-H, DE 2 DE JANEIRO DE 1891 (REFORMA BENJAMIN CONSTANT)}

A autorização às Faculdades Livres que originaram a Faculdade de Direito da UFRJ foi outorgada na vigência do Decreto $n^{\circ} 1.232-\mathrm{H}$, que baixou o Regulamento para as instituições de ensino jurídico ligadas (ou dependentes) ao Ministério da 
REFERENTES ÀS FACULDADES LIVRES

Instrução Pública. Foi primeira reforma do ensino jurídico na República ${ }^{20}$, usualmente conhecida como "Reforma Benjamin Constant", mas, antes dela, cabe consignar que o Decreto $\mathrm{n}^{\mathrm{0}}$ 1.036-A, de 14 de novembro de 1890, já havia abolido o ensino do direito eclesiástico (cf. nota 16).

Em 6 de fevereiro de 1891, o Decreto no 1.340 suspendeu provisoriamente as disposições dos regulamentos dos institutos oficiais de instrução, relativas ao provimento, exercício, licenças, faltas, prêmios e jubilações, atingindo o Decreto $\mathrm{n}^{\mathrm{o}}$ 1.232-H. Tais matérias deveriam continuar a ser regidas pelos regulamentos que estavam em vigor por ocasião da expedição do Decreto n ${ }^{0} 1.232-\mathrm{H}$, ou seja, o Decreto no 7.247/1879, diante da suspensão da execução do Decreto n⿳⺈ 9.360/1885. Com isso, ficou suspensa a execução de parte dos capítulos V e VI do Título I do Decreto $\mathrm{n}^{\mathrm{o}}$ 1.232-H/1891 (provimento, exercício, faltas e jubilações) e dos arts. 83 e 237 (prêmios) e 406 (licenças). Ainda em 1891, a Lei no 26, de 30 de dezembro, em seu art. 3ㅜ, III, autorizou o governo a rever os regulamentos das instituições de instrução dependentes do Ministerio da Instrução Publica, vedado aumento de despesa. Com base nesta autorização, em 3 de dezembro de 1892, foi aprovado pelo Decreto no 1.159 o Código das disposições comuns às instituições de ensino superior dependentes do Ministério da Justiça e Negócios Interiores, conhecida como Reforma Fernando Lobo, que substituiu o Decreto no 1.232-H.

Para efeito de delimitação do tema, a análise do Decreto no 1 1.232-H cinge-se aos temas indicados na Introdução ao artigo, novamente nomeados: a) os estabelecimentos autorizados a ministrar ensino jurídico; b) a estrutura curricular dos cursos; c) os exames aplicados pelas Faculdades Livres aos discentes; d) o corpo docente; e) a administração e o corpo deliberativo; f) a divulgação da produção científica; g) os graus conferidos aos concluintes.

\subsection{Os estabelecimentos autorizados a ministrar ensino jurídico}

A Reforma Benjamin Constant manteve a orientação adotada no Império pelo Decreto $\mathrm{n}^{\mathrm{o}} 7.247 / 1879$ de descentralizar o ensino do Direito, até então realizado apenas em estabelecimentos oficiais, no caso, mantidos pelo governo central (imperial). Embora no período imperial a medida não tenha surtido o efeito efetivo de possibilitar a instalação de novas Faculdades livres ou oficiais, a promulgação do Decreto no $1.232-\mathrm{H} / 1891$ e do Decreto ${ }^{\circ}$ 1.159, que lhe sucedeu em 1892, incentivou inegavelmente a instalação quase que imediata de quatro novas Faculdades, todas livres. São elas, por ordem cronológica: Faculdade de Direito da Bahia, autorizada pelo Decreto no 599/1891, Faculdade Livre de Ciências Juridicas e Sociais do Rio de Janeiro, Faculdade Livre de Direito, autorizadas pelo Decreto $\mathrm{n}^{\mathrm{o}}$

${ }^{20}$ Várias reformas do ensino jurídico se sucederam ao Decreto $n^{0} 1.232-\mathrm{H}$ nos anos seguintes ao de sua edição e, em apenas uma década, ocorreram as reformas de 1892 (Decreto no ${ }^{-1.159}$, alterado em 1894 pelo Decreto oㅡ 230), 1895 (Lei no 314) e 1901 (Decreto oㅜ 3.903), porém nenhuma delas voltou a "estatizar" o ensino jurídico, proibindo que particulares mantivessem cursos ou Faculdades. 
639/1891 e Faculdade de Direito de Minas Gerais ${ }^{21}$, autorizada pelo Decreto no 1.289/1893.

Pode-se afirmar que, a despeito de não ter sido a Reforma Benjamin Constant a precursora do ensino livre (não oficial), deve-se a ela a efetividade da descentralização educacional, possibilitando a expansão do ensino jurídico superior no Brasil, até então limitado a estabelecimentos oficiais e apenas em número de dois. No caso da FND/UFRJ, uma de suas precursoras, a Faculdade Livre de Ciências Jurídicas e Sociais, criada em 1882 por Fernando Mendes de Almeida, só foi instalada em 1891 em razão do advento do Decreto no ${ }^{2}$ 1.232-H. Já a Faculdade Livre de Direito foi criada e instalada também nesse ano, constituída pelos advogados e políticos Carlos Antônio Carvalho e José Joaquim do Carmo. Os estabelecimentos autorizados a ministrar ensino jurídico, na sistemática do Decreto $\mathrm{n}^{\mathrm{o}}$ 1.232- $\mathrm{H}$, eram classificados em três categorias administrativas: faculdades federais (Título I), instituições de ensino jurídico fundadas pelos Poderes dos Estados e aquelas fundadas por particulares, tratando destas últimas o Título II.

Em relação às faculdades fundadas pelos Poderes dos Estados, o Decreto era bem lacônico, delas se referindo apenas no art. 418. Tais instituições eram equiparadas às faculdades federais para efeito de validade dos graus conferidos aos concluintes, desde que: as habilitações para matrículas e exames e os cursos fossem idênticos aos das Faculdades federais; 2) se sujeitassem à inspeção do Conselho de Instrução Superior.

Embora o Decreto de 1891 não indicasse quais eram as faculdades federais, seu sucessor, Decreto n⿳ 1.159/1892 as enumerou em seu art. 10: "Para difusão da instrução pública superior manterá o governo duas Faculdades de Direito, uma em São Paulo e outra em Pernambuco; [...]" [grifos nossos], ou seja, as mesmas criadas em 1827 sem nenhum acréscimo.

A análise ficará circunscrita nesta seção ao Título II, Capítulo III (arts. 420 a 426), que trata das Faculdades livres, e será feita comparativamente com o Decreto no 7.247/1879, pois o Decreto no 9.360/1885 teve sua execução suspensa nesse ano (cf. seção 3.5). Todavia, cabe registrar que, nos estabelecimentos oficiais, as Congregações poderiam conceder salas para cursos livres das matérias ensinadas nos mesmos estabelecimentos, previsão já contida no art. 22 do Decreto ${ }^{0}$ 7.247/1879 e mantida pelo Decreto n⿳o $1.232-\mathrm{H}$, que detalhou o procedimento e as

\footnotetext{
${ }^{21}$ A Faculdade Livre de Direito do Estado de Minas Gerais (atual Faculdade de Direito da UFMG), instalada no dia 10 de dezembro de 1892 na cidade de Ouro Preto e transferida em 1898 para Belo Horizonte, foi autorizada na vigência do Decreto no 1.159/1892. O Decreto, em seu art. 311, manteve a disposição do art. 420 do Decreto $\mathrm{n}^{\mathrm{0}}$ 1.232-H quanto ao funcionamento de Faculdades livres e as prerrogativas que lhes foram conferidas. Em 1927, por força da Lei estadual no 956, de 7 de setembro, a Faculdade foi incorporada à Universidade de Minas Gerais, criada pela referida lei.
} 
condições e prazo para concessão desta autorização no Capítulo XII do Título I.

$\mathrm{O}$ art. 420 autorizava o funcionamento das Faculdades Livres, "estabelecimentos particulares" que já estivessem em funcionamento e tivessem sido aprovados na inspeção do Conselho de Instrução Superior. Prosseguia o dispositivo reproduzindo a mesma redação do art. $21, \S 2^{\circ}$, do Decreto $\mathrm{n}^{\underline{\mathrm{o}}}$ 7.247/1879: "As Faculdades livres terão o direito de conferir aos seus alunos os graus acadêmicos que concedem as Faculdades federais, uma vez que eles tenham obtido as aprovações exigidas pelos estatutos destas para a colação dos mesmos graus". Com base neste dispositivo foram reconhecidos os cursos das Faculdades de Direitoda Bahia e das faculdades predecessoras da FND.

Na linha do Decreto $n^{-}$7.247/1879 (art. 21, § $3^{\text {o }}$ ), o art. 421 previa que os exames das Faculdades livres seriam feitos de conformidade com as leis, decretos e instruções que regulassem os exames das Faculdades federais e valeriam para a matricula nos cursos destes. Nota-se mais uma equiparação das prerrogativas das Faculdades livres com as oficiais. A fiscalização estatal do cumprimento da norma se dava através da visita de comissários inspetores nomeados pelo Conselho de Instrução Superior para assistir aos exames e informar sobre a sua regularidade. $\mathrm{O}$ assunto será aprofundado na seção 4.3.

Outra equiparação era tratada no art. 422 (equivalente ao art. 21, $\S 4^{\mathrm{o}}$ do Decreto no 7.247/1879) no tocante ao currículo, tema a ser versado na seção 4.2. Em cada Faculdade livre deveriam ser ministradas, pelo menos, todas as matérias que constituíssem o programade uma faculdade federal.

As sanções às Faculdades livres pelo descumprimento das disposições legais pelos gestores ou pela congregação poderiam ser das seguintes espécies, de acordo com os arts. 424 e 425, que mantiveram as mesmas sanções contidas no art. 21, $\S \S 6^{\circ}$ e $7^{\circ}$, do Decreto $n^{\circ}$ 7.247/1879: a) censura particular ou pública do governo, b) multa e c) suspensão das atividades e d) cassação do título de Faculdade livre. A penalidade de multa era aplicada em caso de reincidência, quando a censura não tivesse se mostrado eficaz para cessar a irregularidade, variando seu valor entre o mínimo de quinhentos mil réis ao máximo de um conto de réis (os mesmos valores nos dois Decretos em que pese a distância de mais de duas décadas entre eles). $O$ tempo de suspensão não deveria ser excedente a dois anos, com manifestação prévia obrigatória do Conselho de Instrução Superior; tal manifestação não era exigida pelo Decreto $n^{-0} 7.247 / 1879$. Enquanto durasse a suspensão, a Faculdade livre ficava impedida de conferir graus acadêmicos, sob pena de nulidade. A sanção máxima de cassação do título e das prerrogativas a ele inerentes dependia da comprovação de prática de abusos pelas Faculdades livres quanto a identidade dos indivíduos nos exames (uma pessoa fazendo prova no lugar de outra) e na colação dos graus. Na vigência do Decreto $\mathrm{n}^{\mathbf{o}}$ 7.247/1879, o ato governamental de cassação deveria ser submetido à aprovação do Poder Legislativo, exigência suprimida pelo Decreto $\mathrm{n}^{\mathrm{o}}$ 1.232-H. Cabia ao governo, ouvido o Conselho de Instrução Superior, o direito de mandar 
proceder a inquérito para apuração e prova dos fatos. Entretanto, pela disposição do art. 426, correspondente ao art. 21, $\S 8^{\circ}$, do Decreto $n^{\circ}$ 7.247/1879, a Faculdade livre que houvesse sido privada do título poderia recupera-lo se conseguisse provar que se reconstituiu de maneira a oferecer inteira garantia de que os abusos cometidos anteriormente não se repetiriam.

Antes da finalização desta seção, cabe consignar que o Decreto $n^{0}$ 1.232-H não previa a constituição de um patrimônio como condição para o reconhecimento de uma faculdade livre. Tal exigência passou a existir em razão da disposição do art. $5^{\circ}$ da Lei $\mathrm{n}^{\mathrm{o}}$ 314, de 30 de novembro de 1895, in verbis:

Art. $5^{\mathbf{o}}$ As Faculdades Livres, para serem reconhecidas e poderem gozar das regalias e vantagens estabelecidas na legislação vigente, deverão ter um patrimônio de 50:000\$ [cinquenta contos de réis], representado por apólices da dívida pública geral ou pelo edifício em que as mesmas funcionarem e provar uma frequência nunca inferior a 30 alunos por espaço de dois anos, além da observância do regime de ensino prescrito nesta lei.

Parágrafo único. Às atuais Faculdades Livres é concedido o prazo de cinco anos para a constituição deste patrimônio.

\subsection{Estrutura curricular dos cursos}

A Reforma Benjamin Constant manteve a pluralidade de cursos e graus nas Faculdades de Direito (Ciências Jurídicas e Ciências Sociais), mas inovou criando um terceiro curso - o de notariado (art. $2^{\circ}$ ). Este curso era de curta duração, 2 anos, sendo composto por apenas quatro cadeiras: explicação sucinta do direito pátrio constitucional e administrativo, explicação sucinta do direito pátrio criminal, civil e comercial, no $1^{\underline{0}}$ ano ou série, explicação sucinta do direito pátrio processual e prática forense, no $2^{\circ}$ ano ou série. Este regime de cursos múltiplos vigorou até 1895, quando a Lei $n^{\mathrm{o}}$ 314, de 30 de novembro, em seu art. 3o, aboliu os cursos de ciências jurídicas, de ciências sociais e de notariado, permitindo que os cursos em andamento continuassem por mais três anos (ciências jurídicas), por mais dois anos (ciências sociais) e por mais um ano (notariado) se neles houvesse estudante matriculado. Com a mudança, o único curso oferecido pelas Faculdades passou a ser o de Direito, que voltou a ter duração de cinco anos (art. $\left.1^{\circ}\right)$.

Apesar da autonomia que gozavam as faculdades livres em certos aspectos (cf. seção 4.5), algumas imposições existiam, dentre elas a necessidade de serem ensinadas, pelo menos, todas as matérias que integrassem o programa de uma faculdade federal (art. 422 do Decreto $\mathrm{n}^{\mathrm{o}}$ 1.232-H); com isso, no mínimo, a estrutura curricular era comum.

Os cursos de ciências jurídicas e de ciências sociais, no regime do Decreto $\mathrm{n}^{\mathrm{o}}$ 1.232-H,tinham o seguinte currículo:

- Ciências Jurídicas, com 11 matérias em 4 anos ou séries, assim 
distribuídas por ano: $1^{0}$ ano: filosofia e história do direito (inédita) e direito público e constitucional; $2^{\underline{o}}$ ano: direito romano, direito criminal, incluindo o direito militar, direito civil, direito comercial, incluindo o direito marítimo; $3^{\text {o }}$ ano: medicina legal, direito civil e direito comercial; $4^{\circ}$ ano: história do direito nacional, processo criminal, civil e comercial, noções de economia política e direito administrativo e prática forense.

- Ciências Sociais, com 8 matérias em 3 anos ou séries, assim distribuídas por ano: $1^{\mathrm{o}}$ ano: filosofia e história do direito (inédita), direito público e constitucional; $2^{\underline{o}}$ ano: direito das gentes, diplomacia e história dos tratados, economia política, higiene pública; $3^{-}$ano: ciência das finanças e contabilidade do Estado; noções de legislação comparada sobre o direito privado e ciência da administração e direito administrativo.

Além da exclusão da matéria de direito eclesiástico, já mencionada, o currículo de 1891 suprimiu a matéria de direito natural, substituída pela de filosofia e história do direito.

\subsection{Os exames aplicados pelas Faculdades Livres aos discentes}

Em razão da determinação contida no art. 421 do Decreto no $1.232-\mathrm{H}$, os exames das Faculdades livres seriam feitos "de conformidade com as leis, decretos e instruções que regularem os das Faculdades federais" e valeriam para a matrícula nos cursos destas. Por esta razão, optou-se por delimitar a análise das disposições da Reforma Benjamin Constant relativas ao corpo discente a este tema, que os regimentos não poderiam alterar.

Desde 1825 os Estatutos do Visconde da Cachoeira já dispunham sobre os exames aos alunos dos cursos jurídicos (Capítulo XI); no Decreto nº 1.232-H, o tema era disciplinado no Capítulo XVIII.

Os exames durante o curso eram prestados após o encerramento das aulas, mesmo se os examinandos não fossem alunos da instituição. De acordo com o art. 306, no dia seguinte ao último dia de aulas, haveria reunião da congregação para designar os examinadores que comporiam as comissões julgadoras e a ordem de aplicação dos exames, mas a prova escrita tinha que ser a primeira (art. 314).

As comissões julgadoras eram constituídas pelos lentes catedráticos da série ${ }^{22}$ e, na ausência de algum, pelos lentes substitutos. Se não houvesse lente para integrar alguma comissão, o diretor estava autorizado a nomear para os exames os professores particulares que fossem necessários. Para os impedimentos que

${ }^{22}$ A título de ilustração, a comissão examinadora dos exames do $3^{\circ}$ ano ou série do curso de ciências jurídicas seria composta pelos lentes das cadeiras de medicina legal, direito civil e direito comercial; no curso de ciências sociais, a comissão seria composta pelos lentes de ciência das finanças e contabilidade do Estado, noções de legislação comparada sobre o direito privado, e ciência da administração e direito administrativo. 
ocorressem no decurso dos exames, o diretor determinaria a substituição.

Caso a comissão fosse integrada por lentes catedráticos e substitutos, a presidência cabia ao catedrático. Em caso de mais de um catedrático na comissão ou se todos os julgadores fossem desta categoria, ocuparia a presidência o catedrático mais antigo. Para observar os ditames de aplicação dos exames e formação das comissões julgadoras, as Faculdades livres eram obrigadas a ter em seu corpo docente as mesmas categorias de docentes das faculdades federais. A realização dos exames exigia inscrição prévia, tanto para os examinandos internos quanto externos. Findo o prazo, a lista de inscritos era afixada pelo secretário e remetida às comissões julgadoras indicando a ordem de convocação para exame; era expressamente proibida a troca da ordem para exames entre os estudantes.

Os exames constavam de três provas: escrita, oral e prática. A prova prática era aplicada apenas nas cadeiras de prática forense, medicina legal (curso de ciências jurídicas) e higiene pública (curso de ciências sociais). A prova escrita, única realizada "a portas fechadas", era baseada numa lista de pontos do programa da cadeira, mas a definição ocorria somente após o sorteio; já a prova oral abrangia todos os pontos de cada cadeira. Nenhum lente poderia ser obrigado a examinar mais de uma turma por dia em quaisquer das provas. Em termos quantitativos, isso representa, na prova escrita, o máximo de 30 estudantes e o mínimo de 10, salvo se o número de habilitados para o exame fosse menor. Nas provas oral e prática, cada turma de examinandos poderia ser constituída por até 8 alunos.

O examinando que não comparecesse a qualquer prova poderia realiza-la em segunda chamada, mas somente depois de todos os inscritos daquela série terem sido avaliados, figurando, por isso, em lista suplementar.

A prova escrita era dividida etapas: preliminar, aplicação e atribuição das notas.

No dia da prova eram inseridos em uma urna tiras de papel dobradas em quantidade correspondente aos pontos do programa da cadeira que estivesse sendo examinada; cada tira continha um número. O primeiro aluno de cada turma sorteava uma tira, entregava ao presidente da comissão; este, em voz alta, lia o número e verificava o ponto correspondente do programa e esse seria objeto de exame para toda a turma. Feito o sorteio, cada examinando era chamado pelo presidente para receber uma folha de papel rubricada pelo diretor da Faculdade, afim de nela escrever o ponto sobre o qual tinha de dissertar. Encerrava-se, assim, a etapa preliminar.

A aplicação da prova era feita sob a vigilância da comissão, denominada "mesa", incumbindo ao diretor fiscalizar todas as provas. Caso elas ocorressem simultaneamente em várias salas, o diretor deveria passar de umas às outras, como julgasse conveniente. Os examinandos não podiam levar consigo cadernos, escritos ou livros (salvo os de legislação) e comunicar-se entre si durante a prova. Se precisassem sair da sala antes de concluída a prova, só poderiam fazê-lo com 
licença do presidente da mesa, o qual mandaria acompanhar o examinando por pessoa de sua confiança. Aqueles que fossem surpreendidos copiando a prova de qualquer papel, livro, caderno ou objeto levado consigo ou recebido de outrem seriam considerados inabilitados (art. 324).

Findo o tempo de prova - duas horas - os examinandos deveriam entregar à comissão examinadora as provas, finalizadas ou no estado em estivessem. Imediatamente após o encerramento, os membros da comissão se reuniam para examinar as provas, dando cada um por escrito seu parecer e assinando-o. Em seguida, elaborava-se uma lista dos habilitados para a prova oral ou prática, caso a cadeira admitisse essa prova, a ser realizada no dia seguinte.

Tanto a prova oral quanto a prática eram públicas e cada um dos examinadores arguia o examinando por até 20 minutos sobre o ponto do programa sorteado a partir da lista de todos os pontos de cada cadeira. Os examinandos eram arguidos por todos os membros da comissão, começando pelo lente substituto, se houvesse. A arguição observava a ordem de inscrição, tendo direito de precedência os alunos da Faculdade. Ao contrário da prova escrita, não era permitida a saída do examinando antes do encerramento da prova, sob pena de ser considerado inabilitado. Se o abandono da prova fosse motivado por moléstia, o examinando poderia apresentar ao diretor uma justificativa, no dia seguinte ao da prova, a ser apreciada pela congregação. Caso a congregação aceitasse a justificativa, o examinando poderia prestar novamente a prova na data fixada pela comissão examinadora.

Após a aplicação de todas as provas orais (e práticas) da turma, a comissão realizava o julgamento, por votação nominal e separadamente sobre cada cadeira, reduzindo-o a termo no livro para esse fim, assinado pelos membros da comissão julgadora. Para ser aprovado, o examinando deveria obter a totalidade ou a maioria de votos favoráveis. Ademais, existiam as menções "aprovado simplesmente", "aprovado plenamente" e "aprovado com distinção". Na hipótese de a comissão aprovar o candidato por maioria, ele seria qualificado como "aprovado simplesmente"; também caso ele obtivesse a unanimidade dos votos para aprovação em primeira votação, mas em segunda para graduar a aprovação - não obtivesse novamente a unanimidade. A menção "aprovado plenamente" exprimia que o examinando foi aprovado por unanimidade pela comissão nas duas votações. A menção "aprovado com distinção" deveria ser proposta por algum membro na primeira votação e, em nova votação, alcançar unanimidade.

Embora a menção "aprovado simplesmente" não implicasse reprovação e necessidade de prestar novo(s) exame(s), o art. 336 permitia nova inscrição para o mesmo exame na época marcada pela comissão julgadora, contudo, prevaleceria o resultado desse segundo exame, quer fosse de aprovação (em qualquer menção), quer de reprovação. A reprovação em uma ou algumas cadeiras não se estendia para as demais da mesma série. O reprovado poderia 
requerer novos exames sobre as matérias da cadeira ou cadeiras em que tivesse sido inabilitado e, só nesta hipótese, deixaria o exame de ser prestado por séries.

Conforme exposto na seção 4.1, todo o procedimento relativo aos exames narrado nesta seção deveria ser franqueado pelas faculdades livres à fiscalização dos comissários nomeados pelo Conselho de Instrução Superior quanto a sua regularidade. Recorda-se que o art. 425 admitia a cassação do título Faculdade Livre da instituição pela constatação, provada em inquérito de averiguação, de fraudes quanto a identidade dos indivíduos nos exames.

\subsection{O corpo docente}

Desde 1879, as Faculdades livres, bem como os estabelecimentos particulares onde fossem ministradas as matérias que constituíssem o programa de qualquer curso ou Faculdade federal, tinham a prerrogativa de se instalarem e funcionarem sem necessidade de autorização, ressalvadas as providências para sua fiscalização (cf. seção 3.4). Desta forma, com exceção das situações em que se determinasse a sujeição às normas aplicáveis às Faculdades federais, a autonomia vigorava tanto no plano da gestão acadêmica quanto das gestões financeira e administrativa, prerrogativas que não possuíam as Faculdades federais. ${ }^{23}$

Nesse sentido, as normas incidentes aos docentes (lentes) das Faculdades federais eram facultativas para as Faculdades livres ${ }^{24}$, salvo quando lhes fossem impostas normas das faculdades federais, como a participação na congregação diante da determinação do art. 423 do Decreto $\mathrm{n}^{\mathrm{o}}$ 1.232-H e a categorização dos lentes em catedráticos e substitutos para atender à composição das comissões julgadoras dos exames (cf. seção 4.3). Sem embargo, as atribuições da congregação e seus efeitos sobre os lentes permaneciam sob a égide da autonomia na elaboração dos regimentos e os demais aspectos relacionados à organização acadêmica que nãofossem relacionados aos exames e currículos dos cursos.

Em razão da autonomia das Faculdades livres, os regimentos não estavam obrigados, por exemplo, a assegurar os mesmos vencimentos e gratificações pagos aos lentes de estabelecimentos oficiais, licenças, prêmios, realizar concurso

${ }^{23}$ A autonomia para as instituições federais somente ocorreu com a Reforma Rivadávia Corrêa, aprovada pelo Decreto $n^{\circ} 8.659$, de 5 de abril de 1911. De acordo com os arts. $1^{\circ}$ e $2^{\mathrm{o}}$ da Lei Orgânica do Ensino Superior e do Fundamental na República, designação dada ao referido Decreto, os institutos criados pela União [incluindo Escolas e Faculdades] para difusão da instrução superior e fundamental não gozarão de privilégio de qualquer espécie e os institutos, até agora subordinados ao Ministério do Interior, serão, de ora em diante, considerados corporações autônomas, tanto do ponto de vista didático, como do administrativo.

${ }^{24}$ Na vigência do Decreto no 7.247 as Faculdades livres também estavam dispensadas de adotar o mesmo tratamento conferido aos docentes das instituições federais a seus docentes, pois os parágrafos 14 a 20 do art. 20, que tratavam dos lentes, não se aplicavam compulsoriamente às Faculdades livres (art. 21, § $3^{\circ}$ ). 
para contratação de novos lentes ${ }^{25}$ e as condições de jubilamento. Também não tinham os docentes "privados" as obrigações e prerrogativas legais, como a vitaliciedade no $\operatorname{cargo}^{26}$, direito de precedência, uso das insígnias e regência das cadeiras. A distância entre os direitos e vantagens dos lentes "públicos" e lentes "privados" poderia ser tanto maior ou menor dependendo do que dispusesse o regimento de cada Faculdade livre.

No cotejo entre as faculdades oficiais e as livres, embora existissem dois regimes distintos para o corpo docente, o primeiro com as regras legais e o segundo com as normas regimentais, cabe destacar que era possível um professor de Faculdade livre atuar em faculdade oficial para ministrar cadeira, por falta de lente catedrático e substituto e ainda não ter sido aberto o concurso para provimento da vaga. Caso esta hipótese se efetivasse, os professores das Faculdades livres (e até mesmo de cursos livres) tinham assento na congregação com voz e voto, salvo quanto a esse nas deliberações concernentes ao provimento das cadeiras e suas substituições (art. 24 do Decreto no $1.232-\mathrm{H}$ ).

\subsection{Administração e Corpo Deliberativo}

Ao contrário das faculdades federais, as Faculdades livres não estavam obrigadas a adotar as regras para a administração impostas às primeiras. Isso porque o ensino "completamente livre" só seria limitado pela inspeção necessária para garantir as condições de moralidade e higiene (art. $1^{\mathrm{o}}$ do Decreto $\mathrm{n}^{\mathrm{o}}$ 7.247/1879; art. 419 do Decreto $\mathrm{n}^{\mathrm{o}}$ 1.232-H) e outras disposições que fossem expressamente aplicáveis aos estabelecimentos particulares, dentre as quais não se encontrava a direção. Outra norma que permite embasar esta conclusão é o art. 21, $\S 3^{\circ}$ do Decreto $n^{0} 7.247 / 1879$, que estendia às Faculdades livres as disposições dos parágrafos $1^{\mathrm{o}}$ a $5^{\mathrm{o}}$ do art. 20. Nesse mesmo artigo, previa-se no $\S 12$ o critério de nomeação do diretor e no $\S 24$ que suas atribuições e obrigações seriam fixadas em regulamento, só que nenhum dos parágrafos citados consta no rol do art. $21, \S 3^{\circ}$. O Decreto $\mathrm{n}^{\mathrm{o}}$ 1.232-H manteve a autonomia administrativa das Faculdades livres, omitindo no Capítulo III do Título II a obrigatoriedade de adoção das normas do Capítulo III do Título I sobre a direção (arts. 17 a 22).

Também tinham autonomia administrativa as faculdades fundadas pelos

\footnotetext{
${ }^{25}$ Os regimentos das Faculdades livres poderiam autorizar a contratação de um docente sem qualquer processo seletivo; para as faculdades federais, era obrigatório o provimento da vaga de lente substituto por meio de concurso (art. 90 do Decreto no 1.232-H/1891). As regras do concurso em todas as suas etapas eram minuciosamente reguladas na seção segunda do capítulo VI. Conforme o art. 113, as provas eram as seguintes: $1^{a}$, teses e dissertação; $2^{a}$, prova escrita; $3^{a}$, prova oral; $4^{\mathrm{a}}$, arguição sobre os assuntos das provas escrita e oral e $5^{\mathrm{a}}$, prova prática, apenas em concursos para lentes substitutos de prática forense, medicina legal e higiene pública.

${ }^{26}$ Embora o governo republicano tenha mantido a vitaliciedade aos lentes catedráticos e substitutos, inaugurada pelo Decreto $n^{\mathrm{o}}$ 9.360/1885, desapareceu a prerrogativa de gozo das honras e privilégios de desembargador, constante em todos os diplomas imperiais sobre ensino jurídico desde a Lei de 11 de agosto (art, $3^{\circ}$ ).
} 
Estados federados em razão da inexistência de obrigatoriedade de adotar as normas das faculdades federais quanto a sua administração (art. 418).

Em conclusão, cada Faculdade livre poderia dispor em seus estatutos sobre os requisitos para nomeação do diretor e seu substituto, prazo de mandato ou duração indeterminada, atribuições, obrigações e responsabilidades, adotando ou não, mutatis mutandis, as disposiçõespara a direção dos estabelecimentos federais.

O corpo deliberativo das Faculdades livres era a congregação dos lentes, por força do art. 423 do Decreto $\mathrm{n}^{\mathrm{o}}$ 1.232-H/1891, correspondente ao art. 21, $\S 5^{\mathrm{o}}$ do Decreto no 7.247/1879, o mesmo das faculdades federais. Contudo, cada Faculdade livre tinha autonomia para definir em seu regimento as atribuições do colegiado, podendo adotar, mutatis mutandis, as disposições do Capítulo IV, do Título I (arts. 23 a 45) para as congregações das faculdades federais.

\subsection{Divulgação da produção científica}

Um dos aspectos mais importantes da Reforma Benjamin Constant foi a previsão de criação de uma revista acadêmica nas faculdades de Direito federais (art. 207), embora sua adoção não fosse imposta às Faculdades livres em razão da autonomia destas. Na verdade, a Reforma de 1885 também dispôs sobre a criação de uma revista de Ciências Jurídicas e Sociais (Capítulo VIII do Decreto n⿳o 9.360/1885, arts. 188 a 197), porém as disposições ficaram suspensas como todo o Decreto no mesmo ano (cf. seção 3.5). O Decreto n⿳o 7.247 continha disposição sobre a instituição de revista sobre os cursos teóricos e práticos de medicina, não se referindo aos cursos jurídicos (art. 24, § $6^{\circ}$ ).

A base das disposições do Decreto $\mathrm{n}^{\mathrm{0}} 1.232-\mathrm{H}$ sobre a revista acadêmica foi o Decreto $\mathrm{n}^{\mathrm{o}}$ 9.360, com alterações pontuais, uma delas a supressão da discriminação do número de lentes catedráticos e substitutos nomeados pela congregação para cuidar da redação da revista. O segundo Decreto indicava que a comissão redatora seria composta por três lentes catedráticos e dois substitutos, enquanto o primeiro determinava apenas que a comissão seria composta por cinco lentes. Em ambos os diplomas, o redator principal era escolhido pelos membros da comissão e o lente designado pela congregação não poderia recusar o encargo de redator.

A periodicidade da revista também foi alterada na comparação entre os dois Decretos. No de 1885, não havia discricionariedade para fixação da periodicidade pela comissão de redação, pois cada número deveria ser publicado de dois em dois meses. O Decreto de 1891 permitia que a comissão escolhesse entre a periodicidade bimestral ou trimestral, desde que o total anual de páginas fosse de pelo menos seiscentas. Outro ponto inovador neste Decreto foi a previsão do local onde seria impressa a revista, na tipografia oficial ou naquela que oferecesse maiores vantagens às faculdades (art. 209).

A revista não se destinava apenas à publicação de artigos, podendo ser publicadas as decisões da congregação em forma de sumário, a critério do diretor. 
Sem embargo, a preferência para publicação era dos artigos sobre assuntos concernentes às matérias do currículo.

Tanto o Decreto de 1885 quanto o de 1891 previam a permuta de exemplares da revista com periódicos da mesma natureza, nacionais ou estrangeiros, ou academias científicas, através da ação da comissão de redação com o bibliotecário.

A revista não era gratuita e seu valor deveria ser fixado pelo diretor, sendo assegurados aos alunos a impressão do seu nome no exemplar e a redução à metade do preço da assinatura. Para não onerar em excesso a Faculdade com a redução do preço da assinatura aos alunos, o Decreto de 1891 vedava que se fizesse mais de uma assinatura (art. 215), entretanto não foi mantida a sanção de pagamento da assinatura integral, prevista no Decreto de 1885, para aquele que cedesse a assinatura a livreiros ou comerciantes.

\subsection{Graus conferidos aos concluintes}

Apenas com algumas alterações redacionais pontuais e a inclusão do título de notário, o Capítulo XX do Decreto n $1.232-\mathrm{H}$ manteve a orientação quanto aos graus atribuídos pelas Faculdades de Direito e as habilitações correspondentes vigentes desde 1879, embora elas estivessem previstas no Decreto no 3.454, de 26 de abril de 1865, cuja execução foi suspensa.

Em razão da disposição do art. 420 do Decreto no $1.232-H$, as Faculdades livres tinham o direito de conferir aos seus alunos os mesmos graus acadêmicos que outorgassem as Faculdades federais, desde que eles tivessem as aprovações exigidas pelos estatutos destas para a colação de grau. Portanto, os graus de bacharel em ciências jurídicas e de bacharel em ciências sociais eram conferidos indistintamente aos alunos de faculdades federais, estaduais ou livres.

Adicionalmente aos graus citados no parágrafo anterior, nos termos do art. 365 do Decreto no 1.232-H, era outorgado pelas faculdades o grau de doutor em ciências jurídicas e sociais àqueles que fossem bacharéis em ambos os cursos e obtivessem aprovação nas defesas de teses mediante inscrição prévia requerida ao diretor.

Quanto as habilitações conferidas, na linha da Reforma Leôncio de Carvalho, de acordo com o art. 366, o grau de bacharel em ciências jurídicas habilitava para a advocacia, magistratura e ofícios de justiça (ex: escrevente, oficial de justiça); o de bacharel em ciências sociais para os cargos do corpo diplomático e consular e para os cargos de diretor, subdiretor e oficial das secretarias do governo e administração. Os concluintes do curso de notariado fariam jus ao título de notário, que habilitava apenas para os ofícios de justiça (art. 368).

\section{CONSIDERAÇÕES FINAIS}

A pesquisa permitiu aferir que o ensino jurídico, desde a determinação para criação do primeiro curso, em 1825, sempre teve uma regulamentação minuciosa. Embora o texto da Lei de 11 de agosto de 1827 fosse sucinto, os 
Estatutos do Visconde da Cachoeira, que vigoraram até 1831, eram bem prolixos, contendo uma exposição de motivos além de disposições sobre o curso, docentes, discentes, direção e empregados. A nota distintiva era a preocupação com a formação do bacharelando, os métodos de ensino, conteúdos das aulas e compêndios e serem utilizados pelos lentes. Os estatutos subsequentes deixaram aos lentes, no exercício da liberdade de cátedra e com a aprovação da congregação, dispor sobre estes temas. Apesar de o curso jurídico ter sido suficientemente regulado em sucessivas reformas em 1853, 1854 (e seu regulamento complementar do ano seguinte) e 1865, até 1879 somente existiam no País dois estabelecimentos, ambos oficiais e mantidos pelo governo central, os mesmos criados em 1827.

Concluiu-se que a Reforma Leôncio de Carvalho, levada a cabo pelo Decreto $\mathrm{n}^{\mathrm{o}}$ 7.247, alterou substancialmente as bases do ensino jurídico (e superior), haja vista ter destravado a exclusividade da criação de cursos superiores por ato governamental e lhes concedido autonomia praticamente total. A priori, a instituição do ensino "completamente livre", no olhar hodierno, pode ser considerada demasiadamente liberal em razão das prerrogativas dos cursos e faculdades livres expostas numerus apertus na seção 3.4, bem como a possibilidade de se obter um grau acadêmico sem frequência às aulas ou matrícula no curso. Sob outro espectro, constatou-se que a medida buscou disseminar o ensino superior pelo país e multiplicar a quantidade de cursos e estabelecimentos, sem que o governo arcasse com os custos de instalação e manutenção, assumindo apenas as despesas de fiscalização, que mesmo asssim era restrita à "moralidade e higiene" e ao cumprimento das poucas exigências contidas no art. 21, $\S 3^{\circ}$ e art. 20, parágrafos $1^{\circ}$ a $5^{\circ}$. Entretanto, tais medidas não resultaram no aumento de faculdades de direito, o que só ocorreu a partir de 1891.

No tocante ao Decreto $\mathrm{n}^{\mathrm{o}}$ 1.232-H/1891, denominada Reforma Benjamin Constant, regramento em vigor e invocado para a autorização das Faculdades livres precursoras da Faculdade de Direito da UFRJ (FND), bem como da Faculdade de Direito da Bahia, comprovou-se que o diploma manteve as mesmas prerrogativas de seu antecessor quanto aos estabelecimentos particulares de ensino e sua autonomia (v. g. direção, corpo docente, regimento da congregação). Entretanto, de modo inovador, foi permitido pelo art. 418 que os poderes dos Estados federados (ex-províncias) fundassem Faculdades de Direito e conferissem a seus concluintes os mesmos graus das faculdades federais, desde que se submetessem à inspeção do governo federal. Ademais, os casos de imposição das regras das faculdades federais às livres (matérias do currículo, exames e graus conferidos) não se alteraram de 1879 para 1891.

Por fim, o Decreto de 1891 não só conservou a multiplicidade de cursos e currículos (ciências jurídicas e ciências sociais), instaurada em 1865, como criou o curso de notariado, que outorgava o título de notário e habilitava seu portador 
A “CRIAÇÃO” DA FACULDADE DE DIREITO DA UFRJ (FND) E O ENSINO JURÍDICO NO BRASIL EM 1981: ESTUDO ANALÍTICO DE ASPECTOS DA REFORMA BENJAMIN CONSTANT

REFERENTES ÀS FACULDADES LIVRES

ao exercício de ofícios da justiça. No currículo dos cursos de ciências jurídicas e de ciências sociais foi introduzida a matéria de filosofia e história do direito, com supressão da matéria de direito natural.

\section{REFERÊNCIAS BIBLIOGRÁFICAS}

AZEVEDO, Luiz Carlos de. Introdução à História do Direito. São Paulo: RT, 2013.

BRASIL. Câmara dos Deputados. Centro de Documentação e Informação. Criação dos cursos jurídicos no Brasil. Brasília, Rio de Janeiro: Fundação Casa Rui Barbosa, 1977.

BRASIL. Constituição Política do Império do Brasil (25 de março de 1824). Disponível em:

<http://www.planalto.gov.br/ccivil_03/constituicao/constituicao24.htm >. Acesso em: 10 jun. 2021.

CARNEIRO, Maria Francisca. Ensino jurídico: modelo e padrão. Revista Jurídica CESUMAR. v. 10, p. 125-131, 2010.

CASTRO, Flávia Lages de. História do Direito Geral e do Brasil. 13. ed. Rio de Janeiro: Lumen Juris, 2017.

COLEÇÃO DAS LEIS DO IMPÉRIO DO BRASIL DE 1825. Rio de Janeiro: Tipografia Nacional, 1885.

COLEÇÃO DAS LEIS DO IMPÉRIO DO BRASIL DE 1827. Rio de Janeiro: Tipografia Nacional, 1878.

COLEÇÃO DAS LEIS DO IMPÉRIO DO BRASIL DE 1831. Rio de Janeiro: Tipografia Nacional, 1875.

COLEÇÃO DAS LEIS DO IMPÉRIO DO BRASIL DE 1853. Rio de Janeiro: Tipografia Nacional, 1853.

COLEÇÃO DAS LEIS DO IMPÉRIO DO BRASIL DE 1854. Rio de Janeiro: Tipografia Nacional, 1854.

COLEÇÃO DAS LEIS DO IMPÉRIO DO BRASIL DE 1855. Rio de Janeiro: Tipografia Nacional, 1856. 
COLEÇÃO DAS LEIS DO IMPÉRIO DO BRASIL DE 1865. Rio de Janeiro: Tipografia Nacional, 1865.

COLEÇÃO DAS LEIS DO IMPÉRIO DO BRASIL DE 1879. Rio de Janeiro: Tipografia Nacional, 1880.

COLEÇÃO DAS LEIS DO IMPÉRIO DO BRASIL DE 1885. Rio de Janeiro: Tipografia Nacional, 1886.

\section{COLEÇÃO DAS LEIS DA REPÚBLICA DOS ESTADOS UNIDOS DO BRASIL} DE

1891. Rio de Janeiro: Imprensa Nacional, 1892.

MARCOS, Rui de Figueiredo. História do Direito Brasileiro. Rio de Janeiro: Forense, 2014.

NASCIMENTO, Valter Vieira do. Lições de história do direito. Rio de Janeiro: Forense, 1984.

OLIVEIRA, José Sebastião de; TOFFOLI, Vitor. O ensino jurídico em nosso país no período imperial e no primeiro momento republicano, sua evolução históricometodológica e suas consequências na contemporaneidade. In: XXI Encontro Nacional do CONPEDI, 2012.

Uberlândia, MG. Anais do XXI Encontro Nacional do CONPEDI. Florianópolis: Fundação Boiteux, 2012, p. 8648-8675.

SEGURADO, Milton Duarte. O Direito no Brasil. São Paulo: J. Bushatsky, 1973.

VALLADÃO, Haroldo. História do Direito especialmente do Direito Brasileiro. Rio de Janeiro: Freitas Bastos, 1977.

WOLKMER, Antonio Carlos. História do Direito no Brasil. Rio de Janeiro: Forense, 2017.

WOLKMER, Antonio Carlos. Fundamentos de História do Direito. Belo Horizonte: Del Rey, 2010. 